\title{
Rare detections of North Pacific right whales in the Gulf of Alaska, with observations of their potential prey
}

\author{
P. R. Wade ${ }^{1, *}$, A. De Robertis ${ }^{1}$, K. R. Hough ${ }^{1}$, R. Booth ${ }^{2}$, A. Kennedy ${ }^{1}$, R. G. LeDuc ${ }^{3}$, \\ L. Munger ${ }^{4}$, J. Napp ${ }^{1}$, K. E. W. Shelden ${ }^{1}$, S. Rankin ${ }^{3}$, O. Vasquez ${ }^{1}$, C. Wilson ${ }^{1}$ \\ ${ }^{1}$ Alaska Fisheries Science Center, National Marine Fisheries Service, 7600 Sand Point Way NE, Seattle, \\ Washington 98115, USA \\ ${ }^{2}$ Center for Conservation Biology, Department of Biology, University of Washington, Seattle, Washington 98195, USA \\ ${ }^{3}$ Southwest Fisheries Science Center, National Marine Fisheries Service, 3333 N. Torrey Pines Ct, La Jolla, \\ California 92037, USA \\ ${ }^{4}$ Scripps Institution of Oceanography, La Jolla, California 92037, USA
}

\begin{abstract}
The North Pacific right whale Eubalaena japonica was heavily exploited throughout the Gulf of Alaska by both historical whaling and 1960s illegal Soviet catches. It is now extremely rare in this region (2 sightings between 1966 and 2003 and passive acoustic detections on 6 days out of 80 months of recordings at 7 locations). From 2004 to 2006, 4 sightings of right whales occurred in the Barnabus Trough region on Albatross Bank, south of Kodiak Island, Alaska, USA. Sightings of right whales occurred at locations within the trough with the highest density of zooplankton, as measured by active acoustic backscatter. Net trawls through a high-density demersal layer ( 150 to $175 \mathrm{~m}$ ) revealed large numbers of euphausiids and oil-rich C5-stage copepods. Photo-identification and genotyping of 2 whales failed to reveal a match to Bering Sea right whales. Fecal hormone metabolite analysis from 1 whale estimated levels consistent with an immature male, indicating either recent reproduction in the Gulf of Alaska or movements between the Bering Sea and the Gulf of Alaska. Large numbers of historic catches of right whales occurred in pelagic waters of the Gulf of Alaska, but there have been few recent detections in deep water. Given that there is no other location in the Gulf of Alaska where right whales have been repeatedly seen post-exploitation, the Barnabus Trough/Albatross Bank area represents important habitat for the relict population of North Pacific right whales in the Gulf of Alaska, and a portion of this area was designated as critical habitat under the US Endangered Species Act in 2006.
\end{abstract}

KEY WORDS: North Pacific right whale $\cdot$ Eubalaena japonica $\cdot$ Prey $\cdot$ Gulf of Alaska $\cdot$ Kodiak Island · Whaling

\section{INTRODUCTION}

Thousands of North Pacific right whales Eubalaena japonica were killed in the Gulf of Alaska and Bering Sea during intensive commercial whaling in the 1800 s (Scarff 2001). Sightings, primarily from whaling vessels, in the 1950s indicated that a small population of right whales persisted in the eastern North Pacific (Clapham et al. 2004, Shelden et al. 2005, our Fig. 1a).
However, illegal takes of 372 right whales by Soviet commercial whalers in the 1960s reduced the population to a precariously low level (Doroshenko 2000, Brownell et al. 2001). Since then, sightings of right whales have been rare in the eastern North Pacific (Brownell et al. 2001, Clapham et al. 2004, Shelden et al. 2005). Small numbers have been regularly detected in the southeastern Bering Sea since their re-discovery on the central shelf in 1996 (Goddard \& Rugh 1998), 


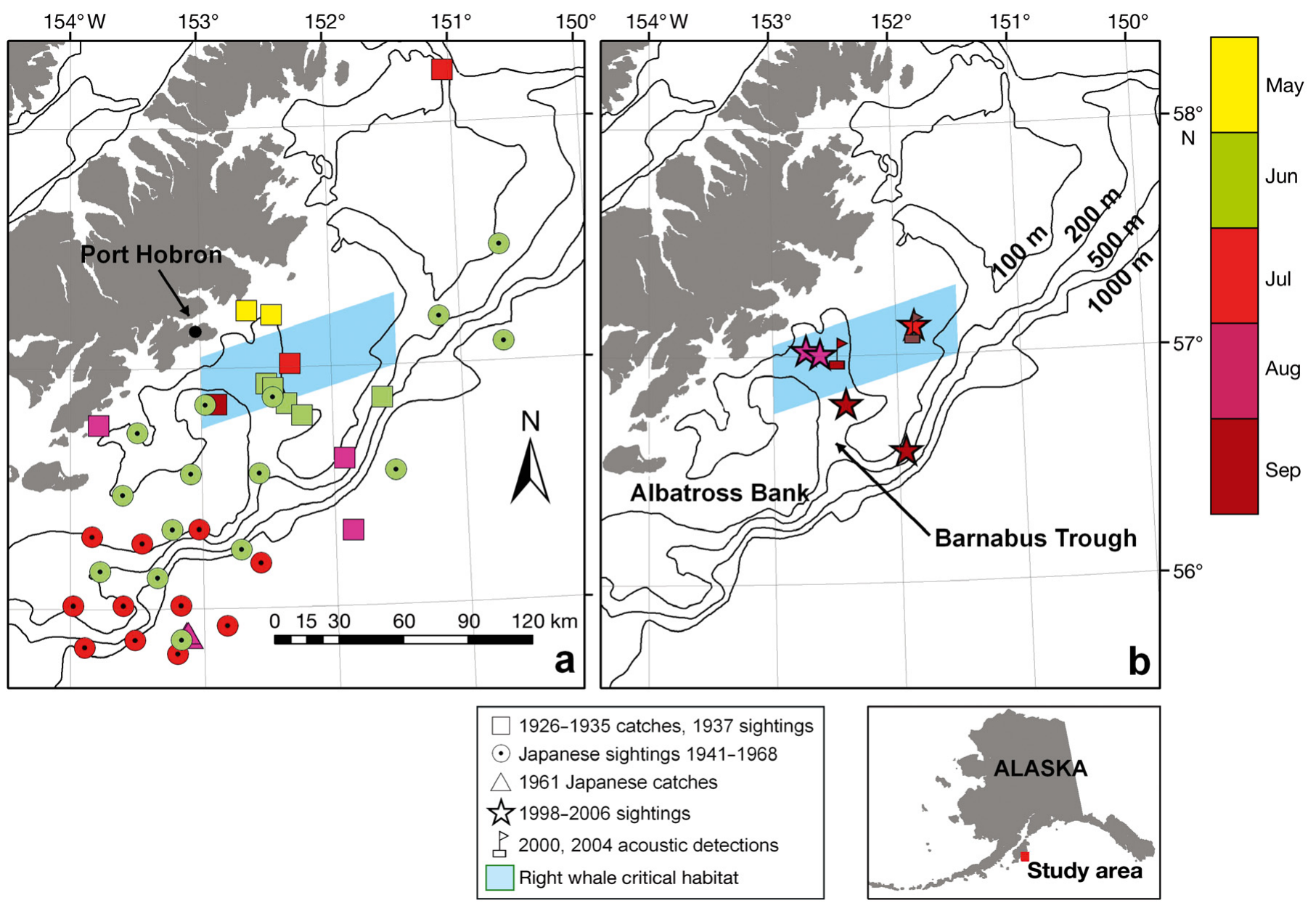

Fig. 1. Eubalaena japonica. Locations of right whales in the vicinity of Kodiak Island, Alaska (USA). Bathymetry lines are shown. (a) Historic sightings and catches from 1926 to 1968. (b) Recent detections since 1998, including 4 sightings (2004 to 2006 ) and 1 passive acoustic detection (2004) first reported in the present study, as well as a 1998 visual detection (Waite et al. 2003) and a 2000 passive acoustic detection (Mellinger et al. 2004). For the locations: type of symbol represents the source and color represents the month (see key). The shaded blue area represents right whale critical habitat designated under the US Endangered Species Act in 2006

with the largest number (19 individual whales) identified in the Bering Sea in 2004 (Wade et al. 2006). A recent study estimated that there are 31 right whales (95\% confidence limits: 23 to 54) in the Bering Sea (Wade et al. 2010).

Sightings of right whales have been even rarer in the Gulf of Alaska, even though the majority of catches in the 1800s came from this region (Townsend 1935, Scarff 1991, 2001). From the 1960s through 2002, only 2 sightings of right whales occurred in the Gulf of Alaska: an opportunistic sighting in March 1979 near Yakutat Bay in the eastern Gulf (Shelden et al. 2005) and a sighting during an aerial survey for harbor porpoise in July 1998 south of Kodiak Island, Alaska, USA (Waite et al. 2003). Both sightings occurred in shelf waters less than $100 \mathrm{~m}$ deep. Here we describe 3 additional visual sightings of North Pacific right whales from National Oceanic and Atmospheric Administration (NOAA) ship surveys in the Gulf of Alaska from 2004 to 2006, as well as 1 passive acoustic detection. We also describe an opportunistic sighting from a commercial fishing vessel in 2006. This triples the number of right whale sightings in the Gulf of Alaska over the last $40 \mathrm{yr}$ from 2 to 6 . All of the visual sightings were in the vicinity of Albatross Bank on the south side of Kodiak Island. As an initial investigation of habitat use, active acoustic backscatter and zooplankton data from the 2004 to 2006 ship surveys were examined to describe the macrozooplankton prey field in the vicinity of 3 of the right whale encounters. 


\section{MATERIALS AND METHODS}

Surveys. In 2004 and 2006, active acoustic fish surveys were conducted from the NOAA ship 'Miller Freeman.' The survey area was designed to cover Barnabus Trough, a canyon that cuts through the Albatross Bank area on the southeastern side of Kodiak Island (Fig. 1b). The surveys were conducted using a fine-scale parallel line pattern with the lines spaced 3 nautical miles (n miles; $5.6 \mathrm{~km}$ ) apart (Fig. 2a,c). A single, experienced marine mammal observer scanned for whales by eye from either the flying bridge (during good weather) or the bridge (during relatively poor weather). When possible, species identification was confirmed with 25-power binoculars.

Additionally, broad-scale surveys for humpback whales Megaptera novaeangliae were conducted in the Gulf of Alaska as part of the Structure of Populations, Levels of Abundance, and Status of Humpback Whales (SPLASH) project in 2004 (on the NOAA ship 'McArthur II') and in 2005 (on the NOAA ship 'Oscar Dyson'). In both years, transects cut across Albatross Bank, an area of relatively high humpback whale density. On each survey, teams of 3 marine mammal
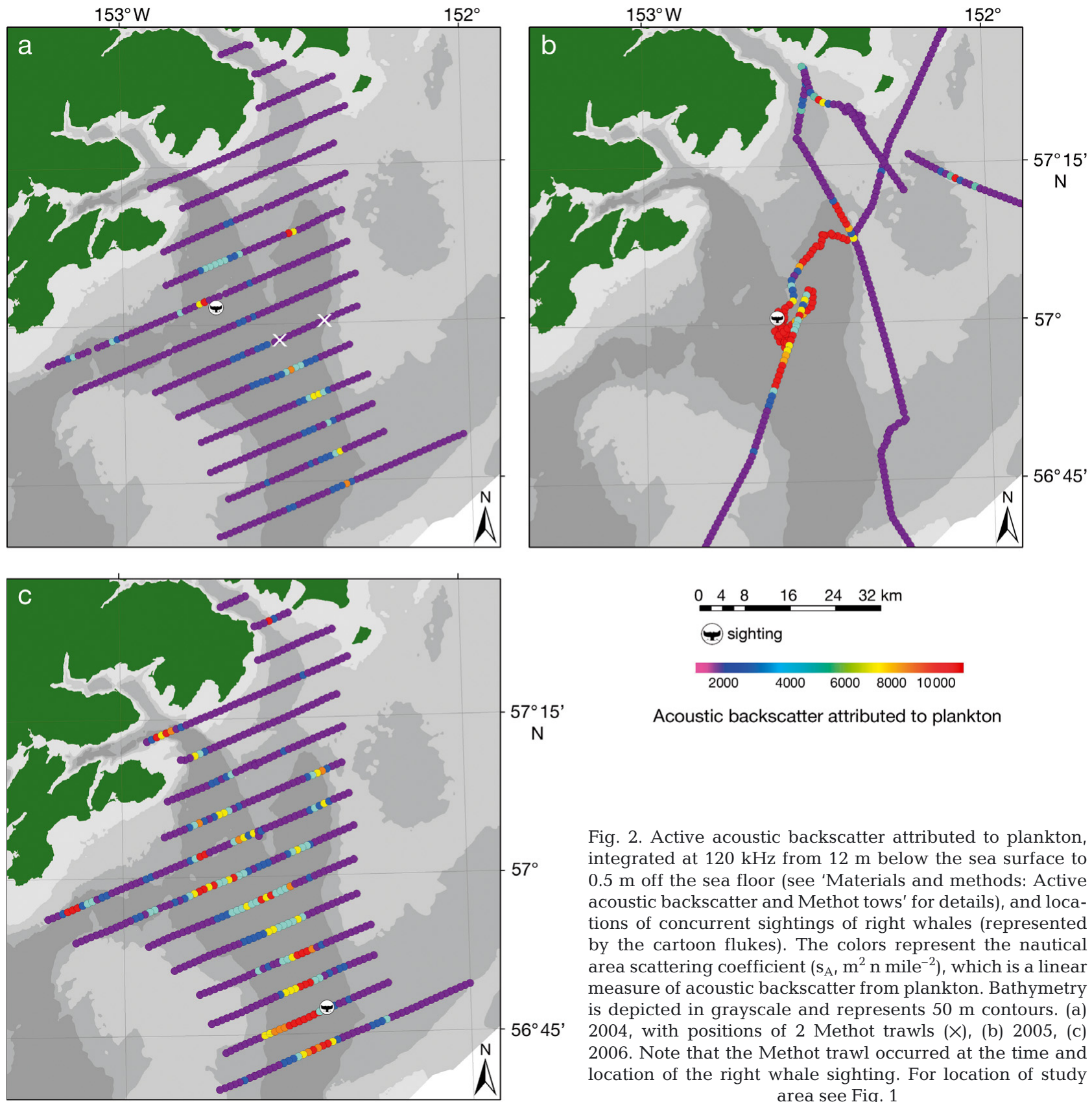

Acoustic backscatter attributed to plankton

Fig. 2. Active acoustic backscatter attributed to plankton, integrated at $120 \mathrm{kHz}$ from $12 \mathrm{~m}$ below the sea surface to $0.5 \mathrm{~m}$ off the sea floor (see 'Materials and methods: Active acoustic backscatter and Methot tows' for details), and locations of concurrent sightings of right whales (represented by the cartoon flukes). The colors represent the nautical area scattering coefficient $\left(\mathrm{s}_{\mathrm{A}}, \mathrm{m}^{2} \mathrm{n}\right.$ mile $\left.{ }^{-2}\right)$, which is a linear measure of acoustic backscatter from plankton. Bathymetry is depicted in grayscale and represents $50 \mathrm{~m}$ contours. (a) 2004, with positions of 2 Methot trawls ( $\times$ ), (b) 2005, (c) 2006. Note that the Methot trawl occurred at the time and location of the right whale sighting. For location of study area see Fig. 1 
observers scanned for whales using 25-power binoculars. On the 2004 'McArthur II' survey, Navy surplus sonobuoys were opportunistically deployed in regions suspected to contain blue whales Balaenoptera musculus and/or right whales, providing acoustic monitoring of right whale vocalizations. Directional frequency and ranging (DIFAR) sonobuoys were used to triangulate the positions of calling whales. When weather permitted, rigid-hulled inflatable skiffs were deployed for close approaches to whales to collect photographs, biopsy samples, and, where possible, fecal samples. Genetic analyses were conducted using methods described by LeDuc et al. (2001). Fecal hormone metabolite analysis was conducted using methods developed for North Atlantic right whales Eubalaena glacialis (Rolland et al. 2005).

Active acoustic backscatter and Methot tows. Active acoustic fish and zooplankton surveys were being conducted from the NOAA ships 'Miller Freeman' (in 2004 and 2006) and 'Oscar Dyson' (in 2005) at the time of the right whale encounters. Active acoustic backscatter data were collected on both ships at a vessel speed of $\sim 12$ knots during daylight hours with calibrated Simrad EK60 echosounders operating at 18 and $120 \mathrm{kHz}$. Backscatter data in the vicinity of the right whale sightings on Albatross Bank and Barnabus Trough were used to assess the biomass of potential right whale prey. Transducers on both ships were located on retractable centerboards, and estimates of backscatter were from $12 \mathrm{~m}$ below the surface to $0.5 \mathrm{~m}$ off the sea floor.

Much of the backscatter in this area is from fish (Wilson et al. 2003), which are unlikely to be potential prey for right whales (e.g. Baumgartner \& Mate 2003, Gregr \& Coyle 2009). To exclude backscatter from fish and produce a backscatter index representative of right whale prey (planktonic organisms such as copepods and euphausiids), a dual-frequency technique was used. The basis for the technique is that active acoustic backscatter at 18 and $120 \mathrm{kHz}$ is strongly frequency dependent for planktonic organisms such as copepods and euphausiids, but generally exhibits much less frequency dependence in fish (e.g. Gauthier \& Horne 2004, Lavery et al. 2007). Although it is difficult to distinguish individual species or taxa with active acoustics, fish and macrozooplankton can be distinguished in many cases due to the strong frequency dependence of plankton (e.g. Miyashita et al. 1998, De Robertis et al. 2010).

Volume backscatter was averaged into 5 ping wide by $5 \mathrm{~m}$ deep cells. Cells in which the volume backscattering was at least 12 decibels $(\mathrm{dB})$ higher at $120 \mathrm{kHz}$ relative to $18 \mathrm{kHz}$ (i.e. $>15.8$-fold higher at $120 \mathrm{kHz}$ ) and in which a signal to noise ratio $>10 \mathrm{~dB}$ was observed (cf. De Robertis \& Higginbottom 2007) were retained for further analysis. This procedure removed fish from the echograms but retained a diffuse scattering layer attributed to planktonic organisms. The nautical area scattering coefficient $\left(\mathrm{s}_{\mathrm{A}}, \mathrm{m}^{2} \mathrm{n}\right.$ mile $\left.^{-2}\right)$, which is a linear measure of the backscatter strength (MacLennan et al. 2002), was integrated at $120 \mathrm{kHz}$ throughout the water column every $0.5 \mathrm{n}$ mile $(0.93 \mathrm{~km})$ along the vessel track, and plotted on a map of the area.

The scattering layers attributed to planktonic organisms were opportunistically sampled in Barnabus Trough ( $\mathrm{n}=10$ hauls in 2004, $\mathrm{n}=0$ in 2005, $\mathrm{n}=3$ in 2006) with a $5.2 \mathrm{~m}^{2}$ frame trawl (Methot 1986) equipped with $2 \times 3 \mathrm{~mm}$ oval mesh and $1 \mathrm{~mm}$ mesh in the filtering cod end. In 2004 on the 'Miller Freeman,' no trawls were conducted in the immediate vicinity of the right whale sighting, although we report the composition from the 2 trawls closest to the right whale sighting. Net tows could not be conducted during the 2005 survey on the 'Oscar Dyson.' In 2006, a trawl was conducted from the 'Miller Freeman' at the time and location where a right whale was encountered.

\section{RESULTS}

Right whales were visually detected in Barnabus Trough in 2004, 2005, and 2006 (Fig. 1b). Right whale calls were passive acoustically detected in Barnabus Trough in 2004. An opportunistic sighting of a right whale from a commercial fishing vessel just at the shelf break in Barnabus Trough was also reported in 2006. Given the rarity of sightings in the Gulf of Alaska, further details on these encounters are presented here.

\section{4 sighting}

On 16 August 2004, a right whale was visually detected (by K. R. Hough) from the 'Miller Freeman' at 13:32 h (all times in Pacific Daylight Time, PDT) at a position of $57^{\circ} 01.68^{\prime} \mathrm{N}, 152^{\circ} 43.80^{\prime} \mathrm{W}$ (Fig. 1b). Water depth was $\sim 170 \mathrm{~m}$. The ship had just passed through a large concentration of humpback whales (minimum of 32 ind.) when 1 right whale was observed near 2 additional humpbacks. The fisheries active acoustic survey briefly broke effort to obtain photographs of the right whale; however, the whale was not observed again due to the high humpback concentration and limited availability of dedicated search time.

\section{4 passive acoustic detection with sonobuoy}

On 28 September 2004, right whale calls were heard intermittently from the 'McArthur II' (by S. Rankin and 
L. Munger) for $\sim 9 \mathrm{~h}$ (from 11:38 to 20:57 h) using passive acoustic hydrophones. Two sonobuoys were used to estimate bearings to the calls at $14: 18 \mathrm{~h}$ and calculate a good position for the right whale calls (as per McDonald \& Moore 2002) at $57^{\circ} 0.60^{\prime} \mathrm{N}, 152^{\circ} 27.84^{\prime} \mathrm{W}$ in Barnabus Trough (Fig. 1b). Marine mammal observers searched visually for right whales in the vicinity, but only humpbacks were seen. Sighting conditions were poor. During the same cruise, sonobuoys were deployed at 20 other locations throughout the Gulf of Alaska, both on and off the shelf, without detecting right whale sounds at any other location.

\section{5 sighting}

On 6 August 2005, the 'Oscar Dyson' was conducting a whale survey transect across Albatross Bank. Two skiffs were deployed in the morning amidst a large aggregation of humpback whales. In the afternoon, while photographing humpback whales, a single right whale was detected from 1 of the skiffs (by $\mathrm{O}$. Vasquez) at $14: 16 \mathrm{~h}$ and at $57^{\circ} 0.61^{\prime} \mathrm{N}, 152^{\circ} 37.02^{\prime} \mathrm{W}$ in Barnabas Trough (Fig. 1b). The bottom depth was 162 m. Weather conditions were good (Beaufort 1). Data collected included full photographs of both sides of the whale, a biopsy tissue sample, and a fecal sample. The right whale was within 250 to $500 \mathrm{~m}$ of 10 to 20 humpback whales, as well as 2 fin whales Balaenoptera physalus.

The whale was easy to approach for photographs and biopsy sampling and a total of $1 \mathrm{hr} 20 \mathrm{~min}$ was spent observing it. During that time, the animal swam at $\sim 5 \mathrm{kn}\left(9.3 \mathrm{~km} \mathrm{~h}^{-1}\right)$, averaging dives of $\sim 7 \mathrm{~min}$ in length (range from $\sim 2$ to $9 \mathrm{~min}$ ). No evidence of feeding at the surface (i.e. surface skimming with head out of the water) was seen, but the presence of a fecal sample indicated recent feeding. The 'Oscar Dyson' followed the track of the whale to active acoustically map prey fields.

The whale was genetically identified as a male. The mtDNA haplotype of the whale occurs in 2 out of 19 whales sampled in the Bering Sea from 1997 to 2004, but microsatellite DNA genotyping analysis confirmed that this was a different whale than any of the whales sampled in the Bering Sea (LeDuc et al. 2001, Wade et al. 2010, R. G. LeDuc unpubl. data). Nor did the whale match any of the previously sampled whales as a potential parent-offspring relationship.

The fecal sample appeared to consist mostly of broken pieces of zooplankton carapaces; however, none were large enough to allow identification of species. Fecal hormone values were $20 \mathrm{ng} \mathrm{g}^{-1}$ estrogen, $4743 \mathrm{ng} \mathrm{g}^{-1}$ androgens (testosterone and metabolites), and $890 \mathrm{ng} \mathrm{g}^{-1}$ progesterone. Based on measured values in North Atlantic right whales (Rolland et al. 2005), these values are consistent with an immature male: the relatively low estrogen and high testosterone values are consistent with values from males, but the testosterone value is well below that of adult males and in the middle of the range seen for juvenile males $(\leq 9 \mathrm{yr}$ of age). Corticosterone was $26 \mathrm{ng} \mathrm{g}^{-1}$, a value again consistent with an immature male, and much lower than measured in calves and yearlings or than that measured in 1 North Atlantic right whale suffering stress as a result of entanglement and injury (Hunt et al. 2006). This suggests the whale was an immature male between the ages of 2 and $9 \mathrm{yr}$, and that it was not under the kind of stress observed in an injured whale.

\section{6 sighting}

On 1 September 2006, a right whale was detected from the 'Miller Freeman' (by K. R. Hough) at 10:26 h at a position of $56^{\circ} 47.46^{\prime} \mathrm{N}$ and $152^{\circ} 24.96^{\prime} \mathrm{W}$ during Beaufort 3 sea conditions. The ship broke from the active acoustic survey transect line and approached the right whale for photographs and video recording. Good quality photographs were taken of the right side of the head and body and of the flukes, and a video recording of several surfacings was made. No evidence of feeding at the surface was seen. The whale slowed and made some variable movements when approached. The ship continued to collect active acoustic data while approaching the whale for photographs. The bottom depth associated with the active acoustic data collected near the whale was $\sim 177 \mathrm{~m}$. A Methot net trawl was conducted in the vicinity of the initial location of the whale. Observations of the whale were ended at $11: 34 \mathrm{~h}$ and $56^{\circ} 46.75^{\prime} \mathrm{N}$ and $152^{\circ} 25.61^{\prime} \mathrm{W}$.

\section{6 opportunistic sighting}

On 24 September 2006, the FV 'Trailblazer' was fishing for halibut near the shelf break on Albatross Bank, near Barnabus Trough. Personnel on the vessel saw a whale illuminated by the vessel's lights at 23:45 $\mathrm{h}$ at a position of $56^{\circ} 34.9^{\prime} \mathrm{N}$ and $151^{\circ} 56.5^{\prime} \mathrm{W}$ (W. Baker pers. comm.; Fig. 1b). Water depth was $\sim 188 \mathrm{~m}$. A clear view of the whale was seen as it sounded: the flukes were reported to be triangular and all-black, and different from other species known to the fishermen (i.e. humpback and gray whales Eschrichtius robustus). They identified the species as a right whale. Our confidence in the accuracy of the identification of the flukes is relatively high, given that they immediately referred to a 
photographic identification guide (designed by NOAA and the Marine Conservation Alliance) distributed to Alaska fishermen to help them distinguish right whales from humpback and gray whales.

\section{Photo-identification results}

Each of the 4 visual sightings was of a single whale, but identification photographs were taken during only 2 of the sightings: both right- and left-side identification photographs were taken for the whale from 2005, and only right-side photographs were available for the whale sighted in 2006. These whales were different individuals, and neither matched any individuals in the North Pacific photo-identification catalogue (A. Kennedy unpubl. data). This includes 16 right-side identifications and 15 left-side identifications from photographs taken in the Bering Sea between 1996 and 2004 (note that some of those individuals have identifications from both sides), and 1 right-side identification from California in 1990 (see http://articles. latimes.com/1990-05-18/local/me-354_1_blue-whale, photographed by Karen LeFever) and 1 left-side identification from Hawaii in 1996 (Salden \& Mickelsen
1999). Additionally, neither of the identified whales from Kodiak is thought to be the same individual reported in 1998 (Waite et al. 2003) because there were no visible lip callosities in the aerial photograph of the whale seen in 1998, whereas the whales seen in 2005 and 2006 both had prominent lip callosities (A. Kennedy unpubl. data). Therefore, at least 3 ind. have been documented from the Kodiak region over the time period 1998 to 2006.

\section{Active acoustic backscatter and zooplankton data}

In 2004, the majority of Barnabus Trough had a relatively low density of zooplankton backscatter, similar to that recorded in the shallower locations on Albatross Bank (Fig. 2a). Higher densities were found in a few locations at the northern end and along the southeastern edge of the trough. The right whale was seen adjacent to one of only 2 locations with very high zooplankton backscatter.

The echogram of $120 \mathrm{kHz}$ backscatter in the vicinity of the right whale location in 2004 showed a strong layer of demersal backscatter and fairly strong nearsurface backscatter (Fig. 3a). Methot trawl catches
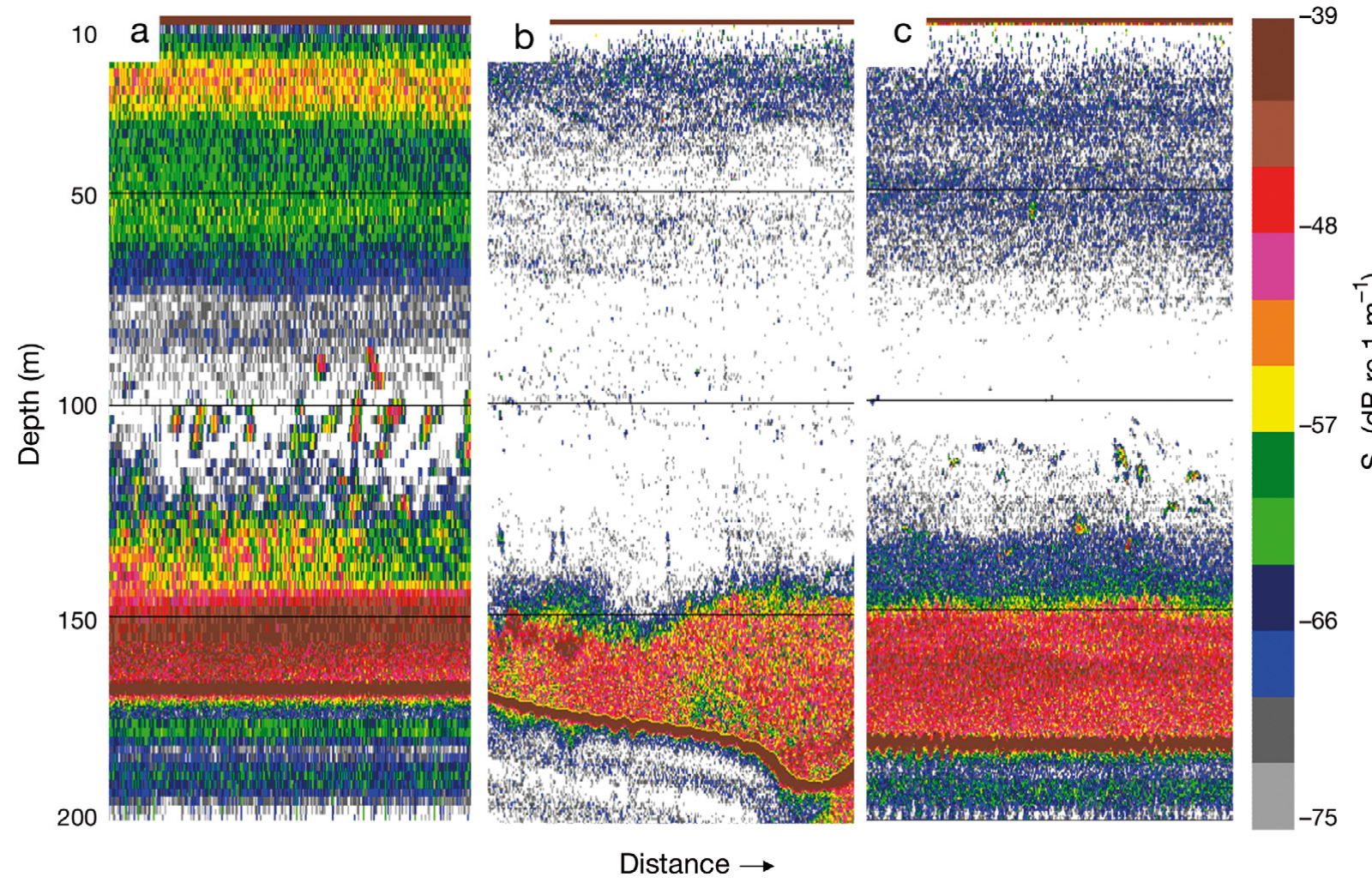

Fig. 3. Echograms of $120 \mathrm{kHz}$ backscatter observed in the vicinity of right whale sightings in (a) 2004, (b) 2005, and (c) 2006. The colors represent $S_{V}$, a logarithmic measure of the active acoustic backscatter strength (see MacLennan et al. 2002 for a definition). The strongest backscatter at $\sim 175 \mathrm{~m}$ in all 3 panels is from the seafloor. Acoustic backscatter from dense aggregations of nearbottom zooplankton is evident within $\sim 50 \mathrm{~m}$ of the bottom at each sighting location 
through the near-bottom layer in other nearby locations in Barnabus Trough showed they were dominated by adult euphausiids primarily of 2 species, Thysanoessa spinifera and $T$. inermis. In the tow (Stn 79) on the eastern flank of the trough (139 m water depth), $T$. inermis juveniles (mean total length = $12.1 \mathrm{~mm}$ ) comprised over $96 \%$ of the catch numerically, and the larger $T$. spinifera (mean total length $=$ $22.4 \mathrm{~mm}$ ) made up ca. $2 \%$ of the catch. Large calanoid copepods were conspicuously absent from the sample. At the tow (Stn 48) closer to the axis of the trough (161 $\mathrm{m}$ water depth), the prey field was somewhat different. Again, T. inermis comprised the majority of the individuals $(>75 \%)$. However, their size distribution was bimodal, with a longer median length than at Stn 79 (22 mm). Large calanoid copepods (C5) Neocalanus cristatus comprised ca. $3 \%$ of the catch. The hauls were not taken in the same location as the right whale, and the hauls did not target the near-bottom layer.

In 2005, very high densities of zooplankton backscatter were observed at the northern end of Barnabus Trough where the right whale was seen (Fig. 2b). The area immediately around the right whale was an extensive area of the highest density backscatter signal. Zooplankton backscatter was lower in the shallower areas of Albatross Bank. In the vicinity of the right whale, the bottom depth was $\sim 162 \mathrm{~m}$, and 3 major layers were seen. A prominent sound-scattering layer was present near the bottom in all cases (Fig. 3b). This layer was much stronger at $120 \mathrm{kHz}$ than at $18 \mathrm{kHz}$, which is consistent with backscattering from largebodied zooplankton such as copepods and euphausiids (De Robertis et al. 2010). A layer of pelagic fish (juvenile pollock Theragra chalcogramma or capelin Mallotus villosus: identifications are based on trawls during the 2004 and 2006 surveys, C. Wilson unpubl.) was seen between $\sim 75$ and $140 \mathrm{~m}$. A near-surface layer of unknown composition (but suspected to be a mixture of jellyfish, fish, and macrozooplankton) was visible at all frequencies to a depth of $\sim 55 \mathrm{~m}$.

In 2006, the majority of Barnabus Trough had relatively high densities of zooplankton backscatter, particularly in the middle of the trough (Fig. 3c). The highest densities were found in a number of locations both at the northwestern and southern ends of the trough. The right whale was seen at the edge of what was the largest measured patch of the highest density zooplankton backscatter at the southern end of the trough.

The active acoustic data collected as the ship approached the right whale in 2006 were similar to the data from 2005. In the vicinity of the whale, the bottom depth was $\sim 177 \mathrm{~m}$ and, again, 3 scattering layers were seen. A near-surface layer visible at all frequencies to a depth of $\sim 55 \mathrm{~m}$ was likely composed of jellyfish, fish, and macrozooplankton. A fairly low backscatter layer of juvenile pollock was observed at mid-depth, and a third very dense layer was observed near the bottom (Fig. 3c). Based on the frequency response (i.e. the ratio of backscattering at different frequencies), this near-bottom layer was likely euphausiids or macrozooplankton. The backscatter values for this layer were very high, and values for this particular part of the transect were among the highest observed. Barnabus Trough generally has much higher backscatter at $120 \mathrm{kHz}$ than other areas of the Gulf of Alaska shelf (A. De Robertis unpubl. data), and net tows through these layers usually result in samples dominated by euphausiids.

The Methot trawl conducted near the whale targeted this layer, fishing at about $10 \mathrm{~m}$ off bottom in the strong demersal layer (e.g. Fig. 3c). This sample contained a mixture of euphausiids and late-stage calanoid copepods. The euphausiid component consisted of juvenile Thysanoessa inermis (mean total length $=13.9 \mathrm{~mm}$, $22 \%$ by number) and larger $T$. spinifera (mean total length $=26.3 \mathrm{~mm}, 7 \%$ by number) which were full of depot lipids. The sample also had high numbers of copepods (59\% by number) that were presumably in a diapause state. The copepod assemblage was $26 \%$ Neocalanus cristatus (C5), $14 \%$ N. flemingeri (C5), $10 \%$ N. plumchrus (C5), and 10\% Calanus marshallae (C5). All copepods appeared rich in depot lipids. Chaetognaths were another abundant taxon (9\%), but probably did not contribute to either the active acoustic returns or the whale diet.

\section{DISCUSSION}

We report 4 visual sightings of right whales south of Kodiak Island from 2004 to 2006, which triples (from 2 to 6) the total number of visual sightings of right whales seen in the Gulf of Alaska since the 1960s. All of these recent sightings were observed in association with dense zooplankton layers in Barnabus Trough. This suggests that Barnabus Trough is an important feeding habitat for right whales in the Gulf of Alaska.

\section{Current distribution and abundance}

Including the detections reported here, all of the right whales found since 1998 have occurred in shelf waters adjacent to Kodiak Island except for a passive acoustic detection from a single deep-water recorder (discussed below). In contrast, 19th century whaling records suggest that the great majority of catches occurred in pelagic waters of the Gulf of Alaska (Townsend 1935, Shelden et al. 2005). In the early 20th century, whalers at the Port Hobron shore station 
reported 13 right whale catches or sightings near Kodiak Island from 1924 to 1937 (Reeves et al. 1985, Brueggeman et al. 1986, Shelden et al. 2005). All of the whales except one were in shelf waters, and 8 of the 13 were located in the Barnabus Trough area (Fig. 1a), although this may be due to the Port Hobron station being located on Sitkalidak Island near Barnabus Trough and to the limited searching range of shorebased whaling vessels. Catches occurred from June through September $(\mathrm{n}=11)$, with 2 unsuccessful chases reported in May. North Pacific right whales are thought to migrate to lower latitudes in winter, although their migratory destinations are not well known (Clapham et al. 2004). Consistent with this migration, passive acoustic recorders on the Bering Sea shelf have detected right whale calls only from May to November (Munger et al. 2008).

In the early 1960s, 3 right whales were taken in August south of Kodiak Island during Japanese scientific research cruises, and sightings from 1941 to 1968 occurred in May ( $\mathrm{n}=3)$, June ( $\mathrm{n}=43)$, July ( $\mathrm{n}=30)$, and August $(\mathrm{n}=1)$ in slope and oceanic waters east and west of the island (Shelden et al. 2005). Soviet whalers killed 251 right whales between 1963 and 1966 in pelagic waters southwest of Kodiak Island (Doroshenko 2000). These whales were near seamounts that are 500 to $1000 \mathrm{~m}$ below the surface in areas where the seafloor is 5000 to $6000 \mathrm{~m}$ deep (Shelden et al. 2005). The biologist on board one of the whaling ships reported that the Soviet whalers used 2 whaling ships, each of which deployed 20 catcher vessels to search for whales, and that every right whale seen during the period 1963 to 1966 was killed (N. Doroshenko pers. comm.). The yearly catches were 141 (1963), 87 (1964), 20 (1965), and 3 (1966; Doroshenko 2000), with essentially identical whaling effort in each year, suggesting that the dramatic decline in catches reflects the severe depletion of the population that occurred. The large number of catcher vessels allowed them to search a broad swath of the ocean, which likely explains why the whalers were able to continue to find the whales even when rare. Additionally, the whales may have been relatively easy to find when rare because the locations of catches described by Doroshenko (2000) indicate that the distribution of the animals was fairly aggregated.

This severe depletion is reflected in the rarity of right whale detections in the Gulf of Alaska today. In recent decades, the only detections of right whales in pelagic waters of the Gulf of Alaska came from passive acoustic recorders. These detections of calls were exceptionally rare; instruments in 7 widespread locations detected right whale calls from only 2 of the locations on only 6 days out of a total of 80 months of recordings (Mellinger et al. 2004), and on only 5 days out of a total of 70 months of recordings from the 5 deep-water stations. The calls were heard at the deepwater station in the Gulf of Alaska $500 \mathrm{~km}$ southwest of Kodiak Island on 5 days in August and September of 2000 , but no calls were detected from 4 other instruments deployed in deep water farther east during 2000 and 2001 (Mellinger et al. 2004). Calls classified as 'probable' right whales were detected from an instrument deployed on the shelf at the location of the aerial visual detection on Albatross Bank on 6 September 2000 (Waite et al. 2003), but no calls were detected from 2 instruments deployed at the base of the continental slope off Albatross Bank just northeast of Barnabus Trough (Mellinger et al. 2004, Munger et al. 2008). As mentioned in 'Results: 2004 passive acoustic detection with sonobuoy', 20 sonobuoy deployments in 2004 throughout the Gulf of Alaska resulted in the detection of right whale calls in Barnabus Trough only. The lack of detection of right whales by passive acoustic recorders does not provide indisputable evidence that there were no right whales in the area, as the whales may not always vocalize or their calls may not always be detected by the automatic algorithms used. However, it is interesting to note the contrasting data from the southeastern Bering Sea where similar instruments on the middle shelf $(<100 \mathrm{~m}$ depth $)$ detected right whale calls on $>6 \mathrm{~d} \mathrm{mo}^{-1}$ in July to October (Munger et al. 2008), despite a population estimated to consist of only 31 ind. (Wade et al. 2010). The lack of detections of right whales in pelagic waters of the Gulf of Alaska may still be partially due to a lack of survey and recording effort in those areas, but the lack of calls in passive acoustic monitoring suggests that right whales are very rare in pelagic waters today. More extensive coverage of shelf and nearshore waters of the Gulf of Alaska during previous ship and airplane surveys for cetaceans (e.g. Dahlheim et al. 2000, Laidre et al. 2000, Zerbini et al. 2006, Hobbs \& Waite 2010, Rone et al. 2010) have not detected right whales other than the single detection near Kodiak Island by Waite et al. (2003). Therefore, the Albatross Bank area represents the only location in the Gulf of Alaska where right whales have been repeatedly detected in the last 4 decades.

The whales photo-identified in 2005 and 2006 have not been seen in the Bering Sea. The genotype of the 2005 whale did not match any Bering Sea whales, and it was not a possible offspring match to any other whale. Historic catch and sighting data do not show any marked hiatus in distribution between the Gulf of Alaska and the Bering Sea (Shelden et al. 2005), and to date, there has been no suggestion that different populations occur in each region. However, baleen whales often show strong matrilineal fidelity to feeding areas; these whales may have always used the Gulf of Alaska 
as a feeding area rather than another location. The whale sampled in 2005 was an immature male, and was therefore born after Gulf of Alaska whales had been severely depleted by illegal Soviet catches in the 1960s. This implies that either some successful reproduction by whales in the Gulf of Alaska, or some exchange with the Bering Sea has occurred that has gone undetected due to the small populations and the small sample sizes involved. Given the evidence from sighting surveys and passive acoustic recorders, there appears to be only a relict number of right whales in the Gulf of Alaska, fewer even than the small number of whales in the Bering Sea (estimated to be 31 whales; Wade et al. 2010). It is likely that surveys in the Barnabus Trough and Albatross Bank area would discover additional whales, but given the rarity of the species there, it would probably not be a large number.

\section{North Pacific right whale prey}

North Pacific right whales are thought to feed primarily on large copepods (Gregr \& Coyle 2009), and we observed dense aggregations of copepods and euphausiids in Barnabus Trough in summer. Stomach contents of North Pacific right whales in the Gulf of Alaska exist for only 3 right whales caught under scientific permit on 22 August 1961 south of Kodiak Island; these whales had all consumed Neocalanus plumchrus (Calanus plumchrus: Omura et al. 1969). This was most likely a mixture of $N$. plumchrus and $N$. flemingerii, as the latter species had not yet been described or distinguished from the former. North Atlantic right whales target areas where dense aggregations of copepods are found above 200 m (Baumgartner \& Mate 2003). This may also be the case for North Pacific right whales. All 4 species of copepods captured in the near bottom layer in 2006 were likely in or entering diapause, an overwintering strategy used by calanoid copepods, as all of these species typically complete their annual feeding in spring and early summer and then migrate to depths of 400 to 2000 m (Miller \& Clemons 1988, Gregr \& Coyle 2009). Neocalanus spp. generally overwinter at much greater depths across the basin (Miller \& Clemons 1988, Miller \& Nielsen 1988, Mackas et al. 1998) or in deep depressions over the shelf (e.g. Prince William Sound). Dense layers of overwintering Calanus have been observed at the sill depths of deep basins in the California Current (Osgood \& Checkley 1997) and around other bathymetric features in the Northwest Atlantic (Baumgartner \& Mate 2003). It is probable that both the euphausiids and copepods have become trapped in the troughs by the interaction of their diel or ontogenetic migrations and the circulation (Koslow \& Ota 1981, Mackas \& Coyle 2005).
The active acoustic backscatter data showed a dense near-bottom layer in all 3 years, and the right whales were found near the highest zooplankton backscatter. The dense near-bottom layers ( 175 $\mathrm{m}$ in each case) were at a depth at which North Atlantic right whales are capable of foraging (Baumgartner \& Mate 2003), suggesting that the whales could be targeting the near-bottom layer. The 1 Methot trawl (in 2006) that occurred at the time and location of a right whale sighting had high densities of copepods and euphausiids, whereas other Methot trawls in Barnabus Trough did not contain many copepods. Euphausiids are typically abundant in Barnabus Trough throughout the summer (A. De Robertis unpubl. data). Although right whales in the western North Atlantic appear to specialize on copepods, there is limited evidence that right whales may also eat euphausiids or similar-sized decapod larvae, and Gregr \& Coyle (2009) noted that their diet may be primarily a function of what they can efficiently capture and filter through their baleen, with prey preference secondary. Omura (1958) reported stomach contents of a right whale in the western North Pacific as containing primarily Calanus plumchrus (Neocalanus plumchrus $+N$. flemingerii), but also some Euphausia pacifica, although the E. pacifica may have been incidentally consumed with the primary prey (copepods). A North Pacific right whale caught by whalers from a British Columbia shore station in 1954 had stomach contents reported to be krill (Nichol et al. 2002). Collett (1909) reported euphausiids half an inch $(1.27 \mathrm{~cm})$ long in a North Atlantic right whale, and in southern right whales there are reports of stomach contents consisting of E. superba (Matthews 1938, Hamner et al. 1988) and the pelagic postlarvae of the crab Munida gregaria (Matthews 1932), which are relatively large. Therefore, we cannot rule out that euphausiids may also be a prey of North Pacific right whales in Barnabus Trough.

Exceptionally dense near-bottom layers of copepods may be available to right whales beginning in late spring or mid-summer, and continuing until midwinter depending on the median time of population diapause for the different species (e.g. Miller \& Clemons 1988, Osgood \& Frost 1994). Gregr \& Coyle (2009) noted that lipid-rich copepods are likely available to right whales in offshore surface waters of the Gulf of Alaska in spring and early summer, but suggested that foraging in late summer and fall (after the copepods begin to enter diapause) is likely to be primarily on the shelf or at the shelf-edge where diapausing copepods may be trapped and unable to migrate down to their maximum diapause depths. Historical locations of right whales on Albatross Bank occurred in all summer months (Fig. 1a). Possible explanations include: interannual variability in the 
time that copepods leave the surface waters and enter diapause, and flexible feeding strategies by the whales (foraging on both surface and deep concentrations of copepods as well as other suitable prey items). There may also have been other prey-concentrating mechanisms active early in the summer, such as the interaction between diel vertical migration and trough circulation (e.g. Koslow \& Ota 1981, Allen et al. 2001). It remains to be determined whether right whales currently use this area only in late summer, or whether their presence has simply gone undetected at other times.

\section{Critical habitat}

The US National Marine Fisheries Service (NMFS) designated critical habitat (as defined under the US Endangered Species Act) for right whales in the North Pacific within the Gulf of Alaska and southeastern Bering Sea in July 2006 (NMFS 2006; Fig. 1b). This decision, in part, came from a determination that 'primary constituent elements' of habitat for the North Pacific right whale are species of large zooplankton in areas where right whales are known or believed to feed. It also came from a determination that there are likely critical threshold densities of zooplankton below which right whale feeding does not occur (e.g. Baumgartner \& Mate 2003), and in the absence of data which describe these densities, recent sightings of right whales (through 2005) were used as a proxy for the existence of suitably dense zooplankton patches. Given that there is no other location in the Gulf of Alaska where right whales have been seen repeatedly, it is clear that the Barnabus Trough/Albatross Bank area represents important habitat for North Pacific right whales in the Gulf of Alaska. Historically, sightings occurred throughout the Barnabus Trough/Albatross Bank area, and both sightings in 2006 were at the southern end of Barnabus Trough (Fig. 1). Further research on the oceanography in this area, particularly on mechanisms that create dense patches of zooplankton, should be undertaken to better describe this important habitat for North Pacific right whales.

Acknowledgements. We thank S. Wasser for assistance with the analysis of fecal hormone levels, R.M. Rolland for help in interpreting the fecal hormone levels, and C. Baier for analysis of the Methot samples. We thank B. Rone, K. Hannan, Y. V. Ivashchenko, E. Lyman, and H. Vukelic for field assistance during the 2005 sighting, W. Baker for providing information on the 2006 opportunistic sighting, and P. Clapham, K. Stafford, and 2 anonymous reviewers for helpful reviews of the manuscript. Reference to trade names does not imply endorsement by NMFS, NOAA.

\section{LITERATURE CITED}

Allen SE, Vinderinho C, Thomson RE, Foreman MGG, Mackas DL (2001) Physical and biological processes over a submarine canyon during an upwelling event. Can J Fish Aquat Sci 58:671-684

Baumgartner MF, Mate BR (2003) Summertime foraging ecology of North Atlantic right whales. Mar Ecol Prog Ser 264: 123-135

Brownell RL Jr, Clapham PJ, Miyashita T, Kasuya T (2001) Conservation status of North Pacific right whales. J Cetacean Res Manag (Spec Issue 2):269-286

Brueggeman JJ, Newby T, Grotefendt RA (1986) Catch records of twenty North Pacific right whales from two Alaska whaling stations, 1917-39. Arctic 39:43-46

Clapham P, Good C, Quinn S, Reeves RR, Scarff JE, Brownell RL Jr (2004) Distribution of North Pacific right whales (Eubalaena japonica) as shown by 19th and 20th century whaling catch and sighting records. J Cetacean Res Manag 6:1-6

Collett R (1909) A few notes on the whale Balaena glacialis and its capture in recent years in the North Atlantic by Norwegian whalers. Proc Zool Soc Lond 1909:91-98

Dahlheim M, York A, Towell R, Waite J, Breiwick J (2000) Harbor porpoise (Phocoena phocoena) abundance in Alaska: Bristol Bay to southeast Alaska, 1991-1993. Mar Mamm Sci 16:28-45

De Robertis A, Higginbottom I (2007) A post-processing technique to estimate the signal-to-noise ratio and remove echosounder background noise. ICES J Mar Sci 64: 1282-1291

> De Robertis A, Mckelvey D, Ressler PH (2010) Development and application of empirical multi-frequency methods for backscatter classification. Can J Fish Aquat Sci 67: 1459-1474

Doroshenko NV (2000) Soviet whaling for blue, gray, bowhead and right whales in the North Pacific Ocean, 1961-1979. In: Yablokov AV, Zemsky VA (eds) Soviet whaling data (1949-1979). Center for Russian Environmental Policy, Moscow, p 96-103

Gauthier S, Horne JK (2004) Acoustic characteristics of forage fish species in the Gulf of Alaska and Bering Sea. Can J Fish Aquat Sci 61:1839-1850

Goddard PD, Rugh DJ (1998) A group of right whales seen in the Bering Sea in July 1996. Mar Mamm Sci 14:344-349

Gregr EJ, Coyle KO (2009) The biogeography of the North Pacific right whale (Eubalaena japonica). Prog Oceanogr 80:188-198

Hamner WM, Stone GS, Obst BS (1988) Behavior of southern right whales, Eubalaena australis, feeding on Antarctic krill, Euphausia superba. Fish Bull 86:143-150

Hobbs RC, Waite JM (2010) Abundance of harbor porpoise (Phocoena phocoena) in three Alaskan regions, corrected for observer errors due to perception bias and species misidentification, and corrected for animals submerged from view. Fish Bull 108:251-267

> Hunt KE, Rolland RM, Kraus SD, Wasser SK (2006) Analysis of fecal glucocorticoids in the North Atlantic right whale (Eubalaena glacialis). Gen Comp Endocrinol 148:260-272

Koslow JA, Ota A (1981) The ecology of vertical migration in three common zooplankters in the La Jolla Bight, April August 1967. Biol Oceanogr 1:107-134

Laidre K, Shelden K, Rugh D, Mahoney B (2000) Beluga, Delphinapterus leucas, distribution and survey effort in the Gulf of Alaska. Mar Fish Rev 62:27-36

> Lavery AC, Wiebe PH, Stanton TK, Lawson GL, Benfield MC, Copely N (2007) Determining dominant scatterers of 
sound in mixed zooplankton populations. J Acoust Soc Am 122:3304-3326

LeDuc RG, Perryman WL, Gilpatrick JW Jr, Hyde J, Stinchcomb C, Carretta JV, Brownell RL Jr (2001) A note on recent surveys for right whales in the southeastern Bering Sea. J Cetacean Res Manag (Spec Issue 2):287-289

Mackas DL, Coyle KO (2005) Shelf-offshore exchange processes, and their effects on mesozooplankton biomass and community composition patterns in the northeast Pacific. Deep-Sea Res II 52:707-725

Mackas DL, Goldblatt R, Lewis AG (1998) Interdecadal variation in the developmental timing of Neocalanus plumchrus populations at Ocean Station $\mathrm{P}$ in the subarctic North Pacific. Can J Fish Aquat Sci 55:1878-1893

MacLennan DN, Fernandes PG, Dalen J (2002) A consistent approach to definitions and symbols in fisheries acoustics. ICES J Mar Sci 59:365-369

Matthews LH (1932) Lobster krill. Discov Rep 5:467-484

Matthews LH (1938) Notes on the southern right whale, Eubalaena australis. Discov Rep 17:169-182

McDonald MA, Moore SE (2002) Calls recorded from North Pacific right whales (Eubalaena japonica) in the eastern Bering Sea. J Cetacean Res Manag 4:261-266

Mellinger DK, Stafford KM, Moore SE, Munger L, Fox CG (2004) Detection of North Pacific right whale (Eubalaena japonica) calls in the Gulf of Alaska. Mar Mamm Sci 20:872-879

Methot RD (1986) Frame trawl for sampling pelagic juvenile fish. Calif Coop Ocean Fish Invest Rep 27:267-278

Miller CB, Clemons MJ (1988) Revised life history analysis for large grazing copepods in the subarctic Pacific Ocean. Prog Oceanogr 20:293-313

Miller CB, Nielsen RD (1988) Development and growth of large, calanid copepods in the Ocean Subarctic Pacific, May 1984. Prog Oceanogr 20:275-292

Miyashita K, Aoki I, Seno K, Taki K, Ogishima T (1998) Acoustic identification of isada krill, Euphausia pacifica Hansen, off the Sanriku coast, north-eastern Japan. Fish Oceanogr 6:266-271

Munger L, Wiggins SM, Moore SE, Hildebrand JA (2008) North Pacific right whale (Eubalaena japonica) seasonal and diel calling patterns from long-term acoustic recordings in the southeastern Bering Sea, 2000-2006. Mar Mamm Sci 24:795-814

Nichol LM, Gregr EJ, Flinn RD, Ford JKB, Gurney R, Michaluk L, Peacock A (2002) British Columbia commercial whaling catch data 1908 to 1967: a detailed description of the B.C. historic whaling database. Can Tech Rep Fish Aquat Sci 2371. Nanaimo, BC

NMFS (National Marine Fisheries Service) (2006) Endangered and threatened species; revision of critical habitat for the northern right whale in the Pacific Ocean. Fed Regist 71:38277-38296. Available at: www.fakr.noaa.gov/ frules/71fr38277.pdf

Omura H (1958) North Pacific right whale. Sci Rep Whales Res Inst Tokyo 13:1-52

Editorial responsibility: Sascha Hooker, St. Andrews, UK
Omura H, Ohsumi S, Nemoto R, Nasu K, Kasuya T (1969) Black right whales in the North Pacific. Sci Rep Whales Res Inst Tokyo 21:1-78

> Osgood KE, Checkley DM Jr (1997) Seasonal variations in a deep aggregation of Calanus pacificus in the Santa Barbara Basin. Mar Ecol Prog Ser 148:59-69

> Osgood KE, Frost BW (1994) Comparative life histories of three species of planktonic calanoid copepods in Dabob Bay, Washington. Mar Biol 118:627-636

Reeves RR, Leatherwood S, Karl SA, Yohe ER (1985) Whaling results at Akutan (1912-39) and Port Hobron (1926-37), Alaska. Rep Int Whal Comm 35:441-457

Rolland RM, Hunt KE, Kraus SD, Wasser SK (2005) Assessing reproductive status of right whales (Eubalaena glacialis) using fecal hormone metabolites. Gen Comp Endocrinol 142:308-317

Rone BK, Douglas AB, Zerbini AN, Morse L, Martinez A, Clapham PJ, Calambokidis J (2010) Results from the April 2009 Gulf of Alaska transect survey (GOALS) in the Navy training exercise area. NOAA Tech Memo NMFS-AFSC209. National Marine Fisheries Service, Seattle, WA

Salden DR, Mickelsen J (1999) Rare sighting of a North Pacific right whale (Eubalaena glacialis) in Hawai'i. Pac Sci 53:341-345

Scarff JE (1991) Historic distribution and abundance of the right whale (Eubalaena glacialis) in the North Pacific, Bering Sea, Sea of Okhotsk and Sea of Japan from the Maury Whale Charts. Rep Int Whal Comm 41:467-489

Scarff JE (2001) Preliminary estimates of whaling-induced mortality in the 19th century North Pacific right whale (Eubalaena japonica) fishery, adjusting for struck-but-lost whales and non-American whaling. J Cetacean Res Manag (Spec Issue 2):261-268

Shelden KEW, Moore SE, Waite JM, Wade PR, Rugh DJ (2005) Historic and current habitat use by North Pacific right whales, Eubalaena japonica, in the Bering Sea and Gulf of Alaska. Mammal Rev 35:129-155

Townsend $\mathrm{CH}$ (1935) The distribution of certain whales as shown by logbook records of American whaleships. Zoologica 19:1-50

> Wade PR, Heide-Jorgensen MP, Shelden KEW, Barlow J and others (2006) Acoustic detection and satellite-tracking leads to discovery of rare concentration of endangered North Pacific right whales. Biol Lett 2:417-419

> Wade PR, Kennedy A, LeDuc RG, Barlow J and others (2011) The world's smallest whale population? Biol Lett. 7:83-85

> Waite JW, Wynne K, Mellinger DK (2003) Documented sighting of a North Pacific right whale in the Gulf of Alaska and postsighting acoustic monitoring. Northwest Nat 84:38-43

Wilson CD, Hollowed AB, Shima M, Walline P, Stienessen S (2003) Interactions between commercial fishing and walleye pollock. Alsk Fish Res Bull 10:61-77

Zerbini AN, Waite JM, Wade PR (2006) Abundance and distribution of fin, humpback and minke whales from the Kenai Fjords to the central Aleutian Islands, Alaska: summer 2001-2003. Deep-Sea Res I 53:1772-1790

Submitted: August 13, 2010; Accepted: November12, 2010

Proofs received from author(s): January 13, 2011 